\title{
Microbiological assay for the determination of cefpirome in raw material and injectable preparation
}

\author{
Tércio Paschke Oppe *, Júlia Menegola, Elfrides Eva Scherman Schapoval \\ Laboratório de Controle de Qualidade Farmacêutico - LCQFar, \\ Faculdade de Farmácia - Universidade Federal do Rio Grande do Sul, Porto Alegre, RS, Brazil \\ Avenida Ipiranga, 2752 - Porto Alegre - RS, 90610-000 \\ *Corresponding author: tercio.oppe@ufrgs.br
}

\begin{abstract}
Cefpirome is a fourth-generation cephalosporin active against a broad spectrum of gram-negative and gram-positive bacterial infections. The present work describe the development and validation of a simple, sensitive and specific agar diffusion bioassay applying cylinder-plate method for quantification of cefpirome in raw material and powder for injectable preparation. The validation method yielded good results and included linearity, precision, accuracy and specificity. The assay is based on the inhibitory effect of cefpirome upon the strain of Kocuria rizophila ATCC 9341 as the test microorganism. The result of assay were treated statistically by ANOVA and the response graphs for standard and sample solutions were linear $(r=0.9948)$ in the range of $0.3-1.2 \mu \mathrm{g} \mathrm{mL} \mathrm{m}^{-1}$, precise (intra-assay: $\mathrm{RSD}=0.11$; inter-assay: $\mathrm{RSD}=0.18$ ) and accurate (mean recovery value $=$ $99.41 \%$ ). A preliminary stability study of cefpirome showed that the microbiological assay is specific for the determination cefpirome in the presence of its degradation products. The proposed microbiological method allows the quantitation of cefpirome in pharmaceutical dosage form and raw material and can be used for the drug analysis in routine quality control.
\end{abstract}

Keywords: Cefpirome, Microbiological Assay, Cephalosporin, Cylinder-plate method, Raw Material, Injectable Preparation; Pharmaceutical dosage form, Method Validation, Quality Control.

\section{Introduction}

Cephalosporins are referred to as the $\beta$ lactam antibiotics, which are among the oldest and most frequently prescribed of naturally occurring antimicrobial agents. These antibiotics have assumed a prominent role in modern antimicrobial therapy due to enhanced intrinsic microbiological activities and favourable safety profile. Traditionally, the cephalosporins are divided into first-, second-, third- and fourth-generation agents $[1,2]$.

Cefpirome, [6R-[6 $\alpha, 7 \beta(Z)]]-1-[[(2-A m i n o-$ 4-thiazolyl)(methoxyimino)acetyl] amino]-2carboxy-8-oxo-5-thia-1-azabicyclo[4.2.0]oct-2em-3-yl]methyl]-6,7-dihydro-5H-

cyclopenta[b]pyrindinium inner salt [3] (Fig. 1), is an injectable broad-spectrum aminothiazolyl cephalosporin, produced as sulfate salt. Both in vitro and in vivo, cefpirome has shown activity against a broad spectrum of gram-negative and gram-positive organisms, including staphicococci, enterococci, Citrobacter species, Enterobacter species, and Pseudomonas aeruginosa [2,4-6]. The increased spectrum of activity, together with high stability against $\beta$-lactamases and rapid transmembrane transport, distinguishes cefpirome as an example of a fourth-generation cephalosporin and its principal use is in treatment for patients' septic shock or several sepsis $[2,4-9]$. Methods have been reported for the determination of cefpirome biological fluids [2,6-12] and pharmaceutical dosage forms [13-15]. Until now, there isn't any report for the determination of cefpirome in raw material and pharmaceutical preparation by biossay. The aim of this study was to develop and validate a microbiological assay of cepfirome in raw material and injectable.

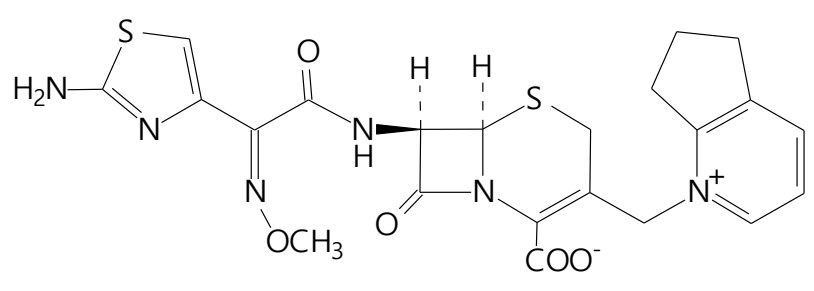

Figure 1. Chemical structure of cefpirome

\section{Material and methods}

\section{Chemicals}

The cefpirome standard (assigned with content of cefpirome $823 \mathrm{mg} / \mathrm{g}$, batch $\mathrm{n}^{\circ}$. C 
150.05 (SS)) was kindly supplied by Aventis Pharma (Frankfurt, Germany), pharmaceuticals dosage form (Cefrom $^{\circledR}$ - injectable) containing cefpirome was obtained commercially from Aventis Pharma (São Paulo, Brazil) and it was claimed to contain $1 \mathrm{~g}$ (as anhydrous base). All reagents used were of analytical reagent grade and were purchased from Fluka, Merck and Oxoid.

\section{Microorganinsm and inoculum}

The cultures of Kocuria rizophila ATCC 9341 were cultivated on Grove-Randall No. 1 agar [16] at freezing and subcultured to another Grove Randall No. 1 agar $24 \mathrm{~h}$ before the assay and were incubated at $35 \pm 2{ }^{\circ} \mathrm{C}$. Using sodium chloride $0.9 \%$ sterile solution, the bacteria was suspended in order to obtained a dilution culture suspension of $25 \pm 2 \%$ turbidity (transmittance) at $580 \mathrm{~nm}$, using a suitable spectrophotometer (Analyser model 800, São Paulo, Brazil) and a $10 \mathrm{~mm}$ diameter test tube of absorption cells against sodium chloride $0.9 \%$ sterile solution as blank. Portions of $2 \mathrm{~mL}$ inoculated sodium chloride $0.9 \%$ were added to $100 \mathrm{~mL}$ Grove Randall No. 11 agar at $47 \pm 2{ }^{\circ} \mathrm{C}$ and used as an inoculated layer.

\section{Reference and samples preparation}

The reference and samples solutions were prepared using an amount of powder equivalent to $20 \mathrm{mg}$ of cefpirome that was transferred to 100 $\mathrm{mL}$ volumetric flask with distilled water followed by making up to final volume with this solvent $\left(200 \mu \mathrm{g} \mathrm{mL}^{-1}\right)$. An aliquot of this solution $(3 \mathrm{~mL})$ was transferred to the $100 \mathrm{~mL}$ volumetric flask and made up to final volume with distilled water $\left(6 \mu \mathrm{g} \mathrm{mL}^{-1}\right)$. Aliquots of 5 and $10 \mathrm{~mL}$ were transferred to 100 and $50 \mathrm{~mL}$ volumetric flasks and the made up to final volume with $0.1 \mathrm{M}$ potassium phosphate buffer $\mathrm{pH} 8.0$ to obtain the concentrations of $0.3,0.6$ and $1.2 \mu \mathrm{g} \mathrm{mL}^{-1}$.

\section{Cylinder-plate assay}

Microbiological cylinder-plate assay (3x3) was used in this study for determination of cefpirome. The agar was composed of two separate layers. A $20 \mathrm{~mL}$ portion of Grove Randall No. 11 agar was poured into $100 \times 20 \mathrm{~mm}$ Petri dish as the base layer. After solidification of this layer, $5 \mathrm{~mL}$ portions of inoculated layer were poured onto the base layer [17-19]. Six stainless steel cylinders of uniform size $(6 \times 8 \times 10 \mathrm{~mm})$ were placed on the surface of inoculated medium. Three alternated cylinders were filled with $200 \mu \mathrm{L}$ of reference and sample solutions (three different concentrations). After incubation $\left(35 \pm 2{ }^{\circ} \mathrm{C}\right.$ for $18 \mathrm{~h})$ the zone diameters of the growth inhibition were measured $(\mathrm{mm})$ using an electronic digital capiler $\left(\right.$ Starret $^{\circledR}$, model 797B, Itu, Brazil). Twelve assays were performed (three assays a day, during four consecutive days) using ten plates in each assay.

\section{Calculations}

To calculate the activity (potency) of cefpirome in raw material and injectable preparation the Hewitt [20] equation was used. The assay was statistically calculated by the linear parallel model and by means of regression analysis and verified using analysis of variance (ANOVA) [17-20].

\section{Method validation}

The method was validated by determination of linearity, precision, accuracy and specificity $[19,21]$. According to the ICH, U.S. and Brazilian Pharmacopoeias $[17,19,21]$, the limits of detection and quantification are not required for this category of assay.

\section{Linearity}

The calibration curve was obtained with three doses of the reference standard. The linearity was evaluated by linear regression analysis, which was calculated by the least-squares regression method. Six assays were performed (3 assays a day) using ten plates in each assay.

\section{Precision}

The precision of the assay was determined by repeatability (intra-assay) and intermediate precision (inter-assay). Repeatability was evaluated by assaying three samples at the same concentration and during the same day. The intermediate precision was verificated by comparing the assays on four different days. The precision is calculated by relative standard deviation (RSD) [19,21,22]. 


\section{Accuracy}

The accuracy was determined by adding known amount of cefpirome reference substance to the samples at the beginning of the process. Amount of powder equivalent to $20 \mathrm{mg}$ of cefpirome (sample) was placed in $100 \mathrm{~mL}$ volumetric flask and amount of $2 \mathrm{mg}$ of cefpirome reference substance were added and made up to final volume with distilled water. Aliquot of this solution $(3 \mathrm{~mL})$ was transferred to the $100 \mathrm{~mL}$ volumetric flask and made up to final volume with distilled water. Aliquots of 5 and $10 \mathrm{~mL}$ were transferred to 100 and $50 \mathrm{~mL}$ volumetric flasks and the made up to final volume with $0.1 \mathrm{M}$ potassium phosphate buffer $\mathrm{pH} 8.0$ to obtain the concentrations of $0.33,0.66$ and $1.32 \mu \mathrm{g} \mathrm{mL}$ respectively. The solutions were submitted to the cylinder-plate assay described above. The percentage recovery of cefpirome reference added was calculated using the equation proposed by AOAC [22].

\section{Specificity}

The specificity was determined by measurement in presence of degradation products. Commercially obtained samples diluted in injectable water at a concentration of $100 \mathrm{mg} \mathrm{mL}^{-1}$ were submitted to accelerated degradation at 40 ${ }^{\circ} \mathrm{C}$, in climatic chamber with controlled humidity Nova Ética 420 LDC (Nova Ética, São Paulo, Brazil), for four days for thermal stress and $6 \mathrm{mg}$ $\mathrm{mL}^{-1}$ and $600 \mu \mathrm{g} \mathrm{mL} \mathrm{m}^{-1}$ for photodegradation studies using UV light for four hours. In the case of the photodegradation studies, the solutions were added into quartz cuvettes, which were exposed to UV light $(254 \mathrm{~nm})$ in a chamber $(17 \mathrm{x}$ $17 \times 100 \mathrm{~cm}$ ) with all mirrored internal surfaces. These solutions were then diluted in $0.1 \mathrm{M}$ potassium phosphate buffer $\mathrm{pH} 8.0$ to obtain the concentrations of $0.3,0.6$ and $1.2 \mu \mathrm{g} \mathrm{mL}^{-1}$ and were assayed against freshly prepared solution of reference standard and sample at the same concentrations. Each sample was analyzed ten times.

\section{Analytical solution stability}

The analytical solutions stability was determined by comparison of quantitation of components in solutions after storage conditions (depends on need) to freshly prepared standards. In this study, the solutions were kept at room temperature for 6 hours and 24 hours when stored refrigerated at $5{ }^{\circ} \mathrm{C}$.

\section{Results and Discussion}

The activity of antimicrobial agents may be demonstrated under suitable condition by their inhibitory effect on microorganisms $[17,19]$. Although the microbiological assay methods involve many steps and are time consuming they can reveal subtle changes not demonstrable by chemical methods [19]. In this work experimental $3 \times 3$ design using three dose levels for each standard and sample were used following the procedure described in Brazilian and European Pharmacopoeias [17,18]. The calculation procedure normally assumes a direct relationship between the observed zone diameter and logarithm of applied dose.

A microbiological assay was proposed as a suitable method for the determination of cefpirome in raw material and pharmaceutical dosage form. The experimental conditions were adjusted to accurately determine the performance of the assay. A strain of Kocuria rizophila ATCC 9341 was found to be an appropriate test microorganism allowing quantitation of cefpirome. Others microorganism were tested (Staphylococcus epidermidis ATCC 12228 and Staphylococcus aureus ATCC 6538P) but no one gave inhibition zone diameters so distinct like Kocuria rizophila.

The assay of antibiotics must be designed to permit examination of the validity of the mathematical model on which the potency equation is based. If a parallel-line model is chosen, the two-log dose-response line of the preparations to be examined and the standard preparation must be linear over the range of doses used in the calculation $[18,22,23]$. For the diffusion assay method, the concentration of the solutions must be chosen to ensure a linear relationship between the logarithm of the dose and the response [24] (Fig. 2). The microbiological assay described in this work was performed using $0.1 \mathrm{M}$ potassium phosphate buffer $\mathrm{pH} 8.0$, water and $0.1 \mathrm{M}$ potassium phosphate buffer $\mathrm{pH} 6.0$ as final solvent at concentration of cefpirome on the 0.05 to $2.0 \mu \mathrm{g} \mathrm{mL}^{-1}$ range using $1 \%$ and $2 \%$ of 
culture suspension of Kocuria rizophila. The best result was obtained with $0.1 \mathrm{M}$ potassium phosphate buffer $\mathrm{pH} 8.0$ as final solvent, $2 \%$ of culture suspension of Kocuria rizophila and good linearity on the $0.3-1.2 \mu \mathrm{g} \mathrm{mL}^{-1}$ range.

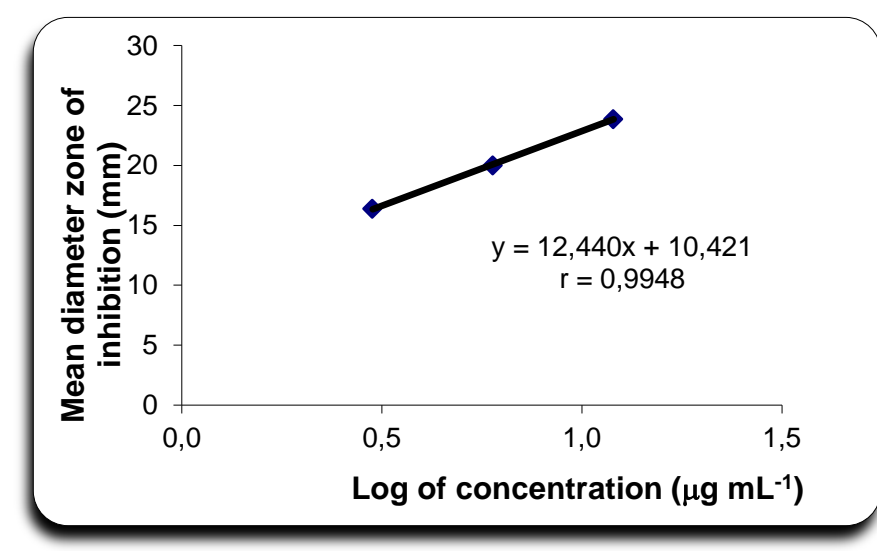

Figure 2. Calibration curve for cefpirome, obtained by the microbiological cylinder - plate assay.

The calibration curve for cefpirome was constructed by plotting log of concentration ( $\mu \mathrm{g}$ $\mathrm{mL}^{-1}$ ) versus zone diameter (mm) (Fig.2). The corresponding mean zone diameters for reference solutions were $16.40 \mathrm{~mm}(\mathrm{RDS}=1.88)$ for the lower dose $\left(0.3 \mu \mathrm{g} \mathrm{mL}^{-1}\right), 20.01 \mathrm{~mm}(\mathrm{RDS}=0.90)$ for the medium dose $\left(0.6 \mu \mathrm{g} \mathrm{mL}^{-1}\right)$ and $23.89 \mathrm{~mm}$ (RDS 1.90) for the higher dose $\left(1.2 \mu \mathrm{g} \mathrm{mL}^{-1}\right)$ (Table 1).

Table 1. Experimental values of Inhibition zone diameters for reference solutions of cefpirome, using $0.1 \mathrm{M}$ potassium phosphate buffer, $\mathrm{pH} 8.0$, by microbiological assay.

\begin{tabular}{ccc}
\hline $\begin{array}{c}\text { Concentration } \\
\left(\boldsymbol{\mu g} \mathbf{~ m L}^{-\mathbf{1}}\right)\end{array}$ & Range of zone size & $\begin{array}{c}\text { Mean diameter zone } \\
\text { of inhibition } \\
(\mathbf{m m} \pm \mathbf{\%} \mathbf{\text { RSD }})\end{array}$ \\
\hline 0.30 & $15.90-17.58$ & $16.40 \pm 1.88$ \\
0.60 & $19.38-21.23$ & $20.01 \pm 0.90$ \\
1.20 & $23.09-24.95$ & $23.89 \pm 1.90$ \\
\hline
\end{tabular}

${ }^{\mathrm{a}}$ Each value is the mean of 6 assays with 10 plates in each.

According British, European and Brazilian Pharmacopoeias $[17,18,25]$, if a parallel-line model is chosen, the two log dose-response lines of the preparation to be examined and the reference preparation must be verifies by validity tests for a given probability, usually $\mathrm{P}=0.05$. The assays were validated by means of the analysis of variance (ANOVA) as described in these official codes.
There are no deviation from parallelism and linearity with results obtained here $\left(F_{\text {calculated }}<F_{\text {critical }} \mathrm{p}=0.05\right)$ as showed in Table 2 . The representative linear equation for cefpirome was $y=12.440 x+10.421$ where $x$ is the log dose and $y$ the diameter zone and the regression coefficient was $r=0.9948$ (Fig. 2).

Table 2. Analysis of variance of the data obtained from the microbiological method for determination of cefpirome.

\begin{tabular}{lcrrr}
\hline $\begin{array}{l}\text { Source of } \\
\text { variation }\end{array}$ & $\begin{array}{c}\text { Degrees of } \\
\text { freedom }\end{array}$ & \multicolumn{1}{c}{$\begin{array}{c}\text { Sum of } \\
\text { Squares }\end{array}$} & \multicolumn{1}{c}{$\begin{array}{c}\text { Mean } \\
\text { squares }\end{array}$} & \multicolumn{1}{c}{$F$} \\
\hline Between & 2 & 168.36 & 84.18 & 755.10 \\
Regression & 1 & 168.29 & 168.29 & $1509.53^{\mathrm{a}}$ \\
Deviation & 1 & 0.07 & 0.07 & 0.67 \\
Within & 15 & 1.67 & 0.11 & ----- \\
Total & 17 & 170.03 & ---- & ---- \\
\hline
\end{tabular}

${ }^{\mathrm{a}}$ Significant at $\mathrm{P}<0.05$

Each value is the mean of 6 assays with 10 plates in each.

The experimental values obtained for the determination of cefpirome in powder for injectable are presented in Table 3. The mean potency of the sample determined by the microbiological assay (721.06 $\mathrm{mg}$ per g) was inside the acceptance criteria. The $278.94 \mathrm{mg}$ remaining was mixture of sulfate, water and sodium carbonate.

Table 3. Results of the determination of cefpirome in powder for injection by microbiological cylinder - plate assay.

\begin{tabular}{|c|c|c|c|c|}
\hline $\begin{array}{c}\text { Sample } \\
\text { powder for } \\
\text { injectable } \\
(\mathrm{mg})\end{array}$ & $\begin{array}{l}\text { Experimental } \\
\text { amount }^{\mathrm{a}}(\mathrm{mg})\end{array}$ & $\begin{array}{l}\text { Potency } \\
\text { (mg per g) }\end{array}$ & $\begin{array}{c}\text { RSD (\%) } \\
\text { Intra- } \\
\text { assay }\end{array}$ & $\begin{array}{l}\text { RSD } \\
(\%) \\
\text { Inter- } \\
\text { assay }\end{array}$ \\
\hline 30.30 & 21.85 & 721.23 & & \\
\hline 30.10 & 21.63 & 718.57 & 0.18 & \\
\hline 30.00 & 21.60 & 719.94 & & \\
\hline 30.30 & 21.84 & 720.89 & & \\
\hline 30.20 & 21.75 & 720.12 & 0.21 & \\
\hline 30.50 & 22.05 & 722.99 & & \\
\hline 30.10 & 21.69 & 720.70 & & \\
\hline 30.00 & 21.66 & 722.10 & 0.11 & 0.18 \\
\hline 30.10 & 21.73 & 721.92 & & \\
\hline 30.10 & 21.67 & 719.90 & & \\
\hline 30.00 & 21.64 & 721.43 & 0.21 & \\
\hline \multirow[t]{2}{*}{30.10} & 21.76 & 722.94 & & \\
\hline & $\begin{array}{r}\text { Mean of } \\
\text { potency }\end{array}$ & 721.06 & & \\
\hline
\end{tabular}


The precision of the assay was determined by repeatability and intermediate precision which results were expressed as the relative standard deviation (RSD) of a series of measurements in the same day and on different days respectively. In the microbiological assay, the number of replications per dose must be sufficient to ensure the required precision. Furthermore, the assay may be repeated and the results combined statistically to obtain the required precision [18]. The repeatability was studied by determination of the samples in three assays, at the same concentration, during the same day under the same experimental conditions. The result obtained shows RSD of 0.11 indicating good intra-assay precision. Interassay variability was calculated from assays on 4 days and shows RSD of 0.18 .

The accuracy was proved by recovery test that are experimental designs to determine the agreement between the values found of the analyte and the real value that analyses [21-22]. The recovery test was performed with three different concentrations and the mean recovery was found to be 99.41 of reference substance (Table 4).

Table 4. Experimental values obtained in the recovery test for cefpirome in powder for injection by microbiological cylinder plate assay.

\begin{tabular}{ccc}
\hline $\begin{array}{c}\text { Amount of } \\
\text { standard } \\
\text { added }(\mathbf{m g})\end{array}$ & $\begin{array}{c}\text { Amount of } \\
\text { standard found } \\
(\mathbf{m g})\end{array}$ & $\begin{array}{c}\text { Percentage recovery }{ }^{\mathrm{a}} \pm \\
\text { RSD }(\%)\end{array}$ \\
\hline 0.300 & 0.304 & $101.37 \pm 0.75$ \\
0.600 & 0.597 & $99.46 \pm 0.83$ \\
1.200 & 1.192 & $99.31 \pm 0.11$ \\
\hline
\end{tabular}

${ }^{\mathrm{a}}$ Mean of twenty determinations.

The specificity of the proposed microbiological assay was studied analysis of degraded samples. The results obtained demonstrate that a decrease occurred in the potency of cefpirome under the conditions used. The results were expressed as a percentage of the drug remaining (Table 5).
Table 5. Results of mean potency of cefpirome reconstituted in aqueous solution after storage at $5{ }^{\circ} \mathrm{C}$ for $24 \mathrm{~h}$, in $0.1 \mathrm{M}$ potassium phosphate buffer, $\mathrm{pH} 8.0$ at room temperature for $6 \mathrm{~h}$ and after degradation by microbiological cylinder - plate assay.

\begin{tabular}{|c|c|c|c|}
\hline Sample & $\begin{array}{l}\text { Concentration } \\
\left(\mu \mathrm{g} \mathrm{mL} \mathbf{L}^{-1}\right)\end{array}$ & $\begin{array}{c}\text { Mean } \\
\begin{array}{c}\text { diameter zone } \\
\text { of inhibition } \\
(\mathbf{m m}), \text { RSD } \\
(\%)^{\mathrm{a}}\end{array} \\
\end{array}$ & $\begin{array}{c}\text { Mean } \\
\text { potency } \\
\text { of sample } \\
(\%)\end{array}$ \\
\hline \multirow{3}{*}{ Standard } & 0.30 & $15.91(1.13)$ & \multirow{3}{*}{100.00} \\
\hline & 0.60 & $19.93(1.60)$ & \\
\hline & 1.20 & $23.91(1.15)$ & \\
\hline \multirow{3}{*}{ Sample } & 0.30 & $15.97(1.40)$ & \multirow{3}{*}{101.40} \\
\hline & 0.60 & 20.09 (1.64) & \\
\hline & 1.20 & $23.93(1.67)$ & \\
\hline \multirow{3}{*}{$\begin{array}{l}\text { Standard solution } \\
\text { stored at } 5^{\circ} \mathrm{C}, \\
24 \mathrm{~h}\end{array}$} & 0.30 & $16.00(1.65)$ & \multirow{3}{*}{100.18} \\
\hline & 0.60 & $19.99(1.32)$ & \\
\hline & 1.20 & 23.87 (1.64) & \\
\hline \multirow{3}{*}{$\begin{array}{l}\text { Sample solution } \\
\text { stored at room } \\
\text { temperature, } 6 \mathrm{~h}\end{array}$} & 0.30 & $15.94(1.95)$ & \multirow{3}{*}{100.44} \\
\hline & 0.60 & $20.08(1.27)$ & \\
\hline & 1.20 & 23.93 (1.58) & \\
\hline \multirow{3}{*}{$\begin{array}{l}\text { Degradated } \\
\text { sample stored at } \\
40{ }^{\circ} \mathrm{C} \text { for } 4 \text { days }\end{array}$} & 0.30 & ----* & \multirow{3}{*}{----* } \\
\hline & 0.60 & ----** & \\
\hline & 1.20 & ----* & \\
\hline \multirow{3}{*}{$\begin{array}{l}\text { Degradated } \\
\text { sample }(0.6 \mathrm{mg} \\
\left.\mathrm{mL}^{-1}\right) \text { stored at } \\
\text { UV light }(254 \mathrm{~nm}) \\
4 \mathrm{~h}\end{array}$} & 0.30 & ----* & \multirow{3}{*}{----* } \\
\hline & 0.60 & ----* & \\
\hline & 1.20 & ----* & \\
\hline \multirow{3}{*}{$\begin{array}{l}\text { Degradated } \\
\text { sample }\left(6 \mathrm{mg} \mathrm{mL}^{-}\right. \\
\left.{ }^{1}\right) \text { stored at } 40^{\circ} \mathrm{C} \\
\text { for } 4 \mathrm{~h}\end{array}$} & 0.30 & ----* & \multirow{3}{*}{----* } \\
\hline & 0.60 & ----* & \\
\hline & 1.20 & ----* & \\
\hline
\end{tabular}

To generate reproducible and reliable results, the stability of sample solution, standards and reagents must be determined prior to initiating the method validation studies. It is often essential that solutions be stable enough to allow for delays. Samples and standards should be tested over a time period and quantitation of components should be determined by comparison to freshly prepared standards. A stability criterion for assay methods is that sample and standard solutions be stable for under defined storage conditions. Acceptable stability is $2 \%$ change in standard or sample response, relative to freshly prepared standards [26].

The analytical solutions of cefpirome in water (reference - $200 \mu \mathrm{g} \mathrm{mL} \mathrm{mL}^{-1}$ ), kept at refrigerated temperature $\left(5^{\circ} \mathrm{C}\right)$ for 24 hours, and $0.1 \mathrm{M}$ potassium phosphate buffer $\mathrm{pH} 8.0$ (sample 
- 0.3, 0.6 and $1.2 \mu \mathrm{g} \mathrm{mL}^{-1}$ ), kept at room temperature for 6 hours, exhibited no inhibition zone diameters changes (Table 5).

Although the biological assays have a high variability, the results obtained in this assay were very satisfactory. Performed validation proved that microbiological assay is a good method for pharmaceutical analysis of cefpirome in raw material and powder for injection.

\section{Conclusion}

The results indicated that the microbiological cylinder-plate assay hold linearity, precision, accuracy and specificity at concentration ranging from 0.3 to $1.2 \mu \mathrm{g} \mathrm{mL}^{-1}$ being an acceptable method for the routine quality control of cefpirome in raw material and pharmaceutical preparation.

\section{Acknowledgements}

The authors are grateful to Aventis Pharma (Frankfurt, Germany) for providing the cefpirome reference standard, CNPq (Brasília, Brazil) and LCQFar (Porto Alegre, Brazil) by financial support.

\section{References}

1. L.G. Martínez, P.C. Falcó, A.S. Cabeza. Comparison of several methods used for the determination of cephalosporins. Analysis of cephalexin in pharmaceutical samples. J. Pharm. Biomed. Anal. 2002; 29: 405-423..

2. H. Tumah. Fourth-generation cephalosporins: in vitro activity against nosocomial gramnegative bacilli compared with beta-lactam antibiotics and ciprofloxacin. Chemotherapy 2005; 51(2-3): 80-85.

3. The Merck Index Online. Available from: URL: https://www.rsc.org/Merck-Index/

4. L.R. Wiseman, H.M. Lamb. Cefpirome. A review of its antibacterial activity, pharmacokinetic properties and clinical efficacy in the treatment of severe nosocomial infections and febrile neutropenia. Drugs 1997;

54(1):117-140.

H.N. Tumah. In vitro activity of cefepime and cefpirome compared to other third-generation cephem antibiotics against gram-negative nosocomial pathogens. Pharmazie 2004; 59(11): 854-858.

5. J.F. Roos, J. Lipman, C.M. Kirkpatrick. Population pharmacokinetics and pharmacodynamics of cefpirome in critically ill patients against Gram-negative bacteria. Intensive Care Med. 2007; 33: 781-788.

6. U. Hollenstein, M. Brumnner, B. Mayer, S. Delacher, B. Erovic, H.G. Eichler, M. Müller. Target site concentrations after continuous infusion and bolus injection of cefpirome to healthy volunteers. Clin Pharmacol Ther. 2000; 67(3): 229-236.

7. C. Joukhadar, N. Klein, B.X. Mayer, N. Kreischitz, G. Delle-Karth, P. Palkovits, G. Heinz, M. Muller. Plasma and tissue pharmacokinetics of cefpirome in patients with sepsis. Crit. Care Med. 30(7) (2002) 1478-1482.

8. G. MLynarczyk, A. MLynarczyk, A. Bilewska, A. Dukaczewska, C. Golawski, A. Kicman, J. Pupek, I. Serafin, M. Luczak. High effectiveness of the method with cefpirome in detection of extended-spectrum beta-lactamases in different species of gramnegative bacilli. Med Dosw Mikrobiol, 2006; 58(1): 59-65..

9. Y. Mrestani, A. Hartl, R.H. Neubert. Influence of absorption enhancers on the pharmacokinetic properties of non-oral betalactam-cefpirom using the rabbit (Chinchilla) in vivo model. Int. J. Pharm. 2006; 309(1-2): 67-70.

10. N. Rajput, V.K. Dumka, H.S. Sandhu. Disposition kinetics and urinary excretion of cefpirome after intravenous injection in buffalo calves. J. Vet. Sci. 2007; 8(1): 21-25.

11. M. Nikolovski, I.U. Kotsev, P. Panchev. Treatment with cefrom (cefpirom) in severe urological infections. Khirurgiia (Sofiia) 2004; 60(4-5): 39-41.

12. Rajeev Jain V. Voltammetric determination of cefpirome at multiwalled carbon nanotube modified glassy carbon sensor based electrode in bulk form and pharmaceutical formulation. Colloids Surf B Biointerfaces 2011; 87(2): 423-6.

13. Rao KS, Kumar KN, Joydeep D. New Stability Indicating RP-HPLC Method for the Estimation of Cefpirome Sulphate in Bulk 
and Pharmaceutical Dosage Forms. Sci Pharm. (2011); 79(4): 899-907.

14. Zalewski P, Skibiński R, Cielecka-Piontek J, Bednarek-Rajewska K. Development and validation of stability-indicating HPLC method for determination of cefpiromesulfate. Acta Pol Pharm. (2014); 71(5): 731-6.

15. D.C. Grove, W.A. RANDALL, Assay Methods of Antibiotics. A Laboratory Manual, Medial Encyclopedia Inc., New York, NY; 1955, pp. 50-52

16. FARMACOPÉIA BRASILEIRA. Agencia Nacional de Vigilância Sanitária. 5. ed. Brasília; 2010.

17. European Pharmacopoeia, 9th ed, Council of Europe, Strasburg; 2018.

18. The United States Pharmacopeia 41th ed. Rochville: United States Pharmacopoeial Convention; 2018.

19. H. Hewitt, Microbiological assay: An introduction to quantitative principles and evaluation, New York: Academic Press 1977.

20. Validation on Analytical Procedures: Text and Methodology Q2(R1). In: ICH
Harmonised Tripartite Guideline. International Conference on Harmonisation of Technical Requirements for registration of Pharmaceuticals for Human Use 2005.

21. AOAC, Official Methods of Analytical Chemists of AOAC, 15th ed. XVII 1990.

22. Márcia C.N. Costa, Amanda T. barden, Juliana M.M. Andrade, Tércio P. Oppe, Elfrides E.S. Schapoval. Quantitative evaluation of besifloxacin ophthalmic suspension by HPLC, application to bioassay method and cytotoxicity studies. Talanta 2014; 119: 367-374.

23. L.C. Vaucher, A.R. Breier, E.E.S.Schapoval, Microbiological Assay for the Determination of Telithromycin in Tables, J. AOAC Inter. (2006); 89(5): 1398-1402.

24. BRITISH Pharmacopoeia. 2018 London: The Stationery Office; 2018.

25. J. Ermer, Validation in pharmaceutical analysis. Part I: An integrated approach, J. Pharmac. Biom. Anal. 2001; 24: 755-767. 